MACIEJ CZERWIŃSKI

HTTP://ORCID.ORG/ 0000-0002-6602-1299

Uniwersytet Jagielloński w Krakowie

e-mail: maciej.czerwinski@uj.edu.pl

\title{
W podróży do celu. Urok pyłu Vjekoslava Kaleba i Krótka wycieczka Antuna Šoljana
}

Abstract

On the Road to Goal. Vjekoslav Kaleb's Glorious Dust and Antun Šoljan's Short Excursion

In the article a problem of mutual intertwining relationships between two Croatian short novels is taken into consideration. Although Vjekoslav Kaleb's Glorious Dust (1954) and Antun Šoljan's Short Excursion (1965) are set in a different chronotope, namely the former in the Dalmatian hinterland during World War Two and the latter in the Istrian post-war Yugoslav reality, they possess some similar structural features. Among resemblances a motif of journey, taken allegorically as life (conceptual metaphor "life if a journey"), that binds together the two novels, is the most important. The author of this article attempts to investigate the problem of such a concept of journey referring both to the philosophy of existentialism (notably Camus and Sartre) and literary preoccupations concerning the problem of meaningfulness and senselessness of human raison d'être.

Keywords: Croatian novel, existentialism, life as a journey, Vjekoslav Kaleb, Antun Šoljan

Słowa kluczowe: powieść chorwacka, egzystencjalizm, życie jako podróż, Vjekoslav Kaleb, Antun Šoljan

„Aby wypełnić ludzkie serce, wystarczy walka prowadząca ku szczytom. Trzeba wyobrażać sobie Syzyfa szczęśliwym" - odnotował w ostatnich zdaniach Mitu Syzyfa Albert Camus ${ }^{1}$. Syzyf odbywa podróż szczególną, której miarą nie może być osiągnięty cel, lecz konfrontacja z absurdem i pogodzenie z losem.

Zanim kultura europejska, piórem Camusa, podejmie wątek absurdalności wielokrotnego podróżowania do celu, u podstaw ideowych cywilizacji zachodniej przeważały doświadczenia podróży zmierzającej do pewnego celu, którego

\footnotetext{
1 A. Camus, Mit Syzyfa, thum. J. Guze, Warszawa 2001, s. 110.
} 
alegorią jest spełnienie jakiejś obietnicy. Towarzyszyło to literaturze europejskiej od momentu pojawienia się pierwszych źródeł pisanych. Legło u podstaw zarówno wyobraźni antycznej (podróż Odyseusza), jak i judeochrześcijańskiej. Biblijne wyobrażenie świata, w tym starotestamentowa wędrówka do Ziemi Obiecanej czy nowotestamentowy koncept Zbawienia, osnute jest wokół podróży. Zbawienie to nawet więcej - wędrowanie od narodzin do śmierci, od świata doczesnego do wiecznego. Droga krzyżowa jest również podróżą, a nie jest przypadkiem, że Szaweł (św. Paweł) nawrócił się w drodze (do Damaszku). Życie jest podróżą do jakiegoś celu, więc przemieszczanie się w czasie i przestrzeni to, jak zauważyła Anna Wieczorkiewicz, sposób „usensowniania” świata ${ }^{2}$; to zrozumienie własnego wnętrza (wewnętrzne pielgrzymowanie). Podróż w głąb siebie bywa więc w literaturze ujmowana jako dojrzewanie do czegoś (Bildungsroman). W amerykańskiej kulturze literackiej wykształcił się nawet gatunek ,powieść drogi”, którego znakomitym przykładem jest $W$ drodze Jacka Kerouaca.

Traktowanie życia jako podróży do jakiegoś celu jest artystycznym przetworzeniem metaforycznej natury języka naturalnego, w którym życie jest ujmowane w kategoriach wędrówki; stąd mówimy o „początku” i „końcu” życia, o „kierunku” w życiu, o „przechodzeniu” przez życie, o „etapach”, o „,napotykaniu” w życiu różnych rzeczy. Mówimy też o „rozdrożach”, które są odpowiednikiem trudności. Życie jest ujmowane jako podróż, co wynika - jak zauważyli George Lakoff i Marc Johnson - z obecności w naszym systemie poznawczym metafory pojęciowej „,zas to przestrzeń” (,czas to przedmiot nieruchomy, a my posuwamy się w czasie" "). Pojęcia abstrakcyjne, takie jak czas, ujmujemy bowiem w kategoriach pojęć konkretnych, takich jak przestrzeń. Inaczej nie potrafimy ich sobie wyobrazić.

Droga życiowa pojedynczego człowieka nie pozostaje bez wpływu na wyobrażenia o zbiorowości, stąd prawidłowości charakteryzujące życie jednostkowe rzutowane są na kolektyw - grupę religijną czy społeczną, naród, cywilizację, a nawet całą ludzkość. Kultura europejska, aż do progu nowoczesności na przełomie XIX i XX wieku, przeważnie opierała swoją wyobraźnię na metaforze szczęśliwego zakończenia podróży. Chrześcijaństwo dawało nadzieję, że na końcu drogi jest Raj (najpełniejszym literackim tego wyrazem jest wędrówka bohatera Dantego w Boskiej komedii, a także żywoty świętych), a projekty racjonalistyczne - przypieczętowane przez epokę oświecenia - zakładały, że u kresu trudnej i wyboistej podróży przez życie, jako paraboli poznania sensu istnienia, istnieje jakiś lepszy świat (Zadig Woltera). Ideologie narodowe wyrażały przekonanie, że naród podróżuje od stanów niedojrzałych ku spełnieniu, to jest autonomii lub niepodległości (specyficzną tego formułą jest tułaczka patriotów po świecie, wykorzenionych z ojczyzny). Heglizm i marksizm zaś, a następnie stalinizm-leninizm jako szczęśliwy koniec projektowały świetlaną przyszłość zwieńczoną zwycięstwem rewolucji. Wszystkie te wizje zakładały, że droga do szczęścia nie jest łatwa; że należy pokonać trudności - to jest: przejść przez rozdroża - i osiągnąć upragniony cel.

2 A. Wieczorkiewicz, Wędrowcy fikcyjnych światów. Pielgrzym, rycerz i włóczęga, Gdańsk 1996, s. 21.

3 G. Lakoff, M. Johnson, Metafory w naszym życiu, thum. T.P. Krzeszowski, Warszawa 1988. 
Literatura nowoczesna wyartykułowała bezsensowność podróżowania do celu (żadnej obietnicy nie można spełnić), by ostatecznie zakwestionować w ogóle istnienie jakiejkolwiek drogi. Najbardziej drastyczną formułą takiego paradygmatu jest chaotyczne przemieszczanie się w koło lub błądzenie w labiryncie (James Joyce, Franz Kafka), w meandrach własnych myśli (Marcel Proust), czy niekończące się powroty do stanu wyjściowego (Albert Camus). Droga może również prowadzić do rozczarowania (Jądro ciemności Josepha Conrada, Czarodziejska góra Thomasa Manna). Choć współczesna kultura odwołuje się do labiryntów i nomadów (Bieguni Olgi Tokarczuk) czy włóczęgów (Zygmunt Bauman), obok niej na równych prawach pojawiają się wizje życia jako drogi, nawet jeśli prowadzi ona do apokalipsy (Droga Cormacka McCarthy'ego) ${ }^{4}$.

Chorwacka proza literacka w XX wieku urzeczywistniła niemal wszystkie odmiany podróżników-poszukiwaczy sensu, melancholików zmierzających ku samobójstwu (Milutin Cihlar-Nehajev), afektowanych artystów wracających do dzieciństwa (Miroslav Krleža), rewolucjonistów zdążających pewnym krokiem ku świetlanej przyszłości (Josip Barković), nawróconych na tradycyjne wartości komunistów (Slobodan Novak), intelektualistów-odszczepieńców zagubionych w labiryncie miasta (Ranko Marinković), poszukiwaczy prawdy o świecie (Miljenko Jergović) i o sobie samym (Ivana Šojat-Kuči). Wymienione naprędce zjawiska nie wyczerpują omawianej problematyki, ale raczej sygnalizują, że analizowane w niniejszym tekście utwory nie powstały w próżni, lecz są głęboko uwikłane - jako hipoteksty i hiperteksty - w uniwersum wyobraźni literackiej.

Powieści Vjekoslava Kaleba Divota prašine (Urok pytu , 1954) oraz Antuna Šoljana Kratki izlet (Krótka wycieczka, 1965) problematyzują motyw podróżowania w duchu egzystencjalistycznym, czyli takim, które ,afirmuje realność

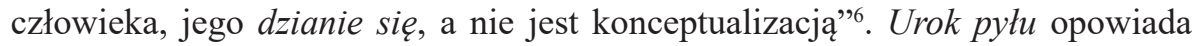
o losach dwóch partyzantów przemieszczających się przez kontynentalną Dalmację w poszukiwaniu zagubionej brygady. Krótka wycieczka w oczywisty sposób nawiązuje do tej pierwszej, choć jej bohaterami nie są partyzanci, lecz młodzi ludzie (oni już mają wojnę ,za sobą”) udający się na ekspedycję mającą na celu odnalezienie jakiegoś bliżej nieznanego klasztoru w interiorze Istrii. Obie powieści łączy naczelny mechanizm strukturalny organizujący narrację - motyw przemieszczania się, podróżowania w jakimś celu. Wędrówka odbywa się w podobnej topografii, w obszarze szeroko rozumianego Śródziemnomorza, którego najważniejszą cechą jest upał, charakterystyczna dla regionu roślinność, ukształtowanie terenu (kamieniste wzgórza). Pokonywaniu przestrzeni towarzyszą postoje, wynikające ze zmęczenia lub z powodu napotkania na drodze jakichś ludzi i/lub

4 O aktualności problemu podróżowania w kulturze współczesnej i jej kontekstach środkowoeuropejskich, wyjaskrawionych przez kryzys migracyjny i pamięć o emigracji z czasów komunistycznych, świadczy chociażby wystawa zatytułowana Podróżnicy. Doświadczenie wędrówki w nowej sztuce z Europy Środkowo-Wschodniej, która odbyła się w 2016 roku w warszawskiej Zachęcie (kurator Magdalena Moskalewicz).

5 Polski przekład: Przydrożny pyt, tłum. Z. Stoberski, Warszawa 1957.

6 C. Milanja, Hrvatski roman 1945-1990. Nacrt moguće tipologije hrvatske romaneskne prakse, Zagreb 1996, s. 47. 
miejscowości; są one niczym wyspy na morzu możliwości i wyrażają przypadkowość podróżowania i ludzkiej egzystencji. Choć już dawno zwracano uwagę na wątek alegorycznej podróży w obu powieściach (Aleksandar Flaker, Vjeran Zuppa, Krešimir Nemec, Velimir Visković, Pavao Pavličić, Jagna Pogačnik), jeszcze nigdy nie próbowano obu książek z sobą porównać i zastanowić się, jaki istnieje między nimi związek. W niniejszym tekście spróbuję wskazać pewne rozwiązanie, które jednak nie wyczerpuje innych możliwości, zwłaszcza że oba utwory są w każdym niemal detalu nadzwyczaj polifoniczne i wieloznaczne.

Zbieżności w modelowaniu świata przedstawionego niech oddadzą dwa wybrane fragmenty. Najpierw Kaleba:

Szli obaj machinalnie, szczędząc sił, z podświadomym uczuciem, że pokonują tę samą, co i przedtem drogę. Przed sobą widzieli ponownie zielone zbocza i szare szczyty górskie, których zdobycie stanowiło dla nich trudny do rozwikłania kłębek. Góry i lasy kryją w sobie mnóstwo dróg i ścieżek, po których wędrują gromady ludzi, nieustannie zdążających do kresu swej drogi. Ile czasu już idą? Dwa, trzy lata, a może dziesiątki lat! Wędrują ludzie po całym świecie, przez góry i pustkowie, płyną przez morza, rodzą się tylko po to, aby zdążać ku dalekiemu, uroczystemu dniu, który wciąż czeka jak wyśniony i wymarzony cel ${ }^{7}$.

A następnie Šoljana:

Wkrótce potem wyszliśmy z miejscowości i skierowaliśmy się, krokiem równym i jednolitym, dalej drogą, zupełnie jak ludzie, którzy muszą jeszcze daleko podróżować. [...] Szliśmy.

Resztki miejscowości - ogrodzenia, sady, jakaś szopa - przemykały obok nas, i szliśmy teraz w jednorodnym suchym krajobrazie, który w ogóle się nie zmieniał. Wzgórza były podobne do siebie, pola i murki kamienne tak bardzo siebie nawzajem przypominały, że zdawało się, iż się ciągle kręcimy wkoło. Droga jednorodnie pełzała między kamieniami szara i okryta pyłem. Nic nie pojawiało się na horyzoncie: ani młyn rzeczny, ani biały koń, ani karczma z winoroślą przy wejściu. Nieprzyjemny cień samotności opadł na naszą małą grupę, niezrozumiały, przeraźliwy jak zachodzące słońce.

Napięcie i samotność nas dyscyplinowały, utwardziły i złączyły jakby żołnierski oddział realizujący ryzykowną misję. Spojrzałem na twarze swoich kompanów, wpatrzone naprzód, ku drodze. Byliśmy małym wojskiem, ale byliśmy jak wojsko. Szliśmy ${ }^{8}$.

W obu wypadkach trudom podróżowania towarzyszy nieprzystępna natura i pył przydrożny - symbol trudu (prašina jak w tytule powieści Kaleba). Podobne tło staje się jednak scenerią dla odmiennych dramatów. Pierwsza powieść opowiada o wojnie, druga o okresie powojennym (zupełnie też wypiera pamięć o niedawnym konflikcie). Bohaterami pierwszej są wyczerpani partyzanci, uparcie zmierzający do swojej brygady, protagonistami drugiej zaś - przedstawiciele zblazowanej młodzieży, szukającej jakiejkolwiek przygody, która mogłaby ich wyrwać z bezproduktywnego letargu. Podczas gdy bohaterowie Kaleba stawiali czoła sytuacjom prawdziwie granicznym, bohaterowie Šoljana zmagają się z defetyzmem i brzemieniem egystencji (o takich problemach protagoniści

\footnotetext{
7 V. Kaleb, Przydrożny pyt, thum. Z. Stoberski, Warszawa 1957, s. 194.

8 A. Šoljan, Kratki izlet, Zagreb 2004, s. 59.
} 
pierwszej powieści, żyjący w poczuciu ciągłego zagrożenia życia, mogli tylko pomarzyć).

Zbieżna jest również sceneria - pejzaż śródziemnomorskiego kontynentu, a więc kamienne i skaliste obszary interioru. W przypadku pierwszej książki jest to nieprzystępne dalmatyńskie Zagórze, w przypadku drugiej zaś - dzika kontynentalna Istria ${ }^{9}$. Obie powieści można potraktować jako głos dwóch pokoleń: jednego bezpośrednio doświadczonego przez wojnę i drugiego żyjącego w jej cieniu. Kaleb urodził się w 1905 roku i był członkiem ruchu oporu, więc doświadczył wojny, czemu dał wyraz w niemal całej swojej twórczości. Šoljan przyszedł na świat w 1932 roku, więc jego młodzieńcze lata przypadły na okres powojenny. Konfrontacja tych dwóch książek umożliwia rozważenie sposobów modelowania (w znaczeniu Łotmanowskim) świata dzieła literackiego i artystycznego przetwarzania dokonujących się modyfikacji światopoglądowych w Jugosławii.

Aby móc właściwie omówić książkę Kaleba, a następnie skonfrontować z powieścią Šoljana, należy ją usytuować w tendencjach prozy wojennej. W okresie od zakończenia wojny w 1945 roku do końca lat sześćdziesiątych dokonały się ważkie zmiany w obrazowaniu motywu partyzanckiej odysei. Można to wiązać ze zmianą dominujących paradygmatów ideologicznych. W latach czterdziestych, gdy przeważał model socrealistyczny, większość powieści ujmowała wędrowanie jako sensowną drogę do celu. Lata pięćdziesiąte wprowadziły przeszkody, które należy pokonać, żeby osiągnąć zamierzony cel (nawet jeśli się zgubi drogę, można ją po chwili odnaleźć). W kolejnej dekadzie pojawiły się powieści, w których podróżowanie nie ma już sensu, więc protagoniści chaotycznie przemierzają jakąś przestrzeń. Tak więc pierwsza faza wyraża przekonanie, że istnieje prawidłowa droga, którą należy pokonać (podróż we właściwym kierunku); druga faza zakłada, że droga wprawdzie istnieje, ale dotarcie do celu wcale nie jest łatwe (błądzenie); a trzecia faza daje wyraz poglądowi, że nie istnieje żadna droga ku lepszemu światu, więc samo podróżowanie nie ma sensu (bezdroża). Te trzy fazy, a w istocie tendencje, są alegorią stosunku do rewolucji: pierwsza wyraża optymizm, druga sceptycyzm, trzecia katastrofizm. Na początku lepszy świat był w zasięgu ręki, następnie stał się trudny do realizacji, ale wciąż możliwy, by na końcu stać się zupełnie nieosiągalny. Jednak alegoryczne znaczenie drogi, choć rzeczywiście odnosi się do walki narodowowyzwoleńczej i do rewolucji, wykracza daleko poza wąski horyzont polityczny. Droga, jej pokonywanie i osiąganie celu są emblematami różnych filozoficznych postaw wobec życia: witalistycznego pozytywizmu, sceptycyzmu i defetyzmu.

Powieść Kaleba na pierwszy rzut oka jest zbudowana schematycznie. Wiele elementów świata przedstawionego bliźniaczo przypomina wzorcowe przedstawienia wojny narodowowyzwoleńczej. Są tutaj wyczerpani partyzanci (nie znamy ich imion, tylko apelatiwa oddające ich właściwości - Chłopiec i Goły ${ }^{10}$ ), heroicznie znoszący swoją niedolę, wyznający wartości ogólnoludzkie, bezwzględni

9 Nie od rzeczy będzie powiedzieć i to, że obaj autorzy w innych swoich książkach eksploatowali motyw podróżowania. Kaleb w prozie Poniženi grad (1969), a Šoljan we wszystkich swoich powieściach, w których podróżowanie do jakiegoś celu kończy się rozczarowaniem.

10 W przekładzie tłumacz zrezygnował z wielkich liter, więc pojawia się ,,chłopiec” i ,goły”. 
wobec wrogów, a łagodni dla zwykłych ludzi. Jest też droga, którą przemierzają - w poszukiwaniu swojej brygady - ale żeby ją odnaleźć, muszą pokonać słabości i przeszkody, które napotykają. A są nimi żołnierze wroga (Niemcy, Włosi, czetnicy, ustasze), są nimi słabości wewnętrzne wynikające ze zmęczenia, głodu i zwątpienia, są nimi wreszcie ograniczenia stawiane przez naturę: kamienie, zarośla, lasy i ukształtowanie terenu (wzgórza i góry). Krajobraz jest istotnym elementem kompozycyjnym, który modeluje stosunek jednostki do przemierzanej drogi; człowiek musi tę drogę przebyć, czy bardziej dobitnie: musi ją pokonać.

Drzewa wychodziły mu naprzeciw z jakąś nieufną obojętnością... Nawet skały tu i ówdzie nieprzyjaźnie zatarasowywały i utrudniały drogę [...] Z lewej strony piętrzyły się jakieś skały, jakby naturalna przeszkoda zakrywająca przed nim coś, co go interesuje, a czego nie może dosięgnąć [...] Z drugiej strony, nieco dalej od niego, wznosiły się pokryte świeżą zielenią buki, nad nimi zaś wierzchołki gór, za którymi w dole płynęła rzeka ${ }^{11}$.

Podobnych scen, wyobrażających przemierzany teren jako ograniczoną przez naturalne przeszkody przestrzeń, która stawia opór słabemu człowiekowi, jest w powieści wiele. Przyczyniają się one do stworzenia „dusznej” atmosfery, poczucia bezsilności wobec przyrody. Jeden z partyzantów mówi: „Muszę pokonać przestrzeń! Muszę iść naprzód"12.

Bohaterowie, pokonując swoje słabości, hartują się - i fizycznie, i emocjonalnie. Książka za sprawą znaczeń alegorycznych przyciągała uwagę ważnych chorwackich badaczy - Pavla Pavličicia ${ }^{13}$ czy Aleksandra Flakera ${ }^{14}$. Ten pierwszy podróż partyzantów porównał do uniwersalnego poszukiwania sensu w życiu, ten drugi - nawet do drogi krzyżowej (nawiązując do interpretacji zaproponowanej przez Slobodana P. Novaka w Historii literatury chorwackiej).

Gdyby niedogodności w podróży łagodził fakt zbliżającego się szczęśliwego finału, wówczas moglibyśmy powiedzieć, że schemat powieści realizuje wzorcowo tendencję drugą (sceptyczną). Tymczasem, mimo iż partyzanci idą w kierunku swojej brygady, mimo iż dokonują nadludzkich czynów, by to osiągnąć, niemal przez całą książkę ma się wrażenie, że nigdzie się nie zbliżają; więcej - właściwie nawet się oddalają. Wynika to $\mathrm{z}$ faktu, że cel ich podróży może się również przemieszczać. Jednak w mniemaniu samych protagonistów, przy którym trwają uparcie do końca, brygada jest czymś nieruchomym, więc staje się złudzeniem, swego rodzaju projekcją powstającą jako odpowiedź na trudy i rozczarowanie. „Widzieli gdzieś hen daleko, daleko przez sobą coś nieokreślonego, ku czemu idą, i to utrwalało się w ich mózgach jako jedyna rzeczywistość"15. A w innym miejscu:

11 V. Kaleb, op. cit., s. 11.

12 Ibid., s. 11.

13 P. Pavličić, Divota prašine kao alegorija, „Adrias” 2011, nr 17, s. 9-30.

14 A. Flaker, Zašto „Divota prašine”? [w:] Komparativna povijest hrvatske književnosti: zbornik radova VIII. (Hrvatske književnost prema europskim /emisija i recepcija/ 1940-1970) sa znanstvenoga skupa održanog 22-23. rujna 2005. godine u Splitu, red. C. Pavlović, V. Glunčić-Bužančić, Split 2006, s. 279-286.

15 V. Kaleb, op. cit., s. 138-139. 
Mamy przed sobą daleką drogę. Kiedy się ściemni, zaraz położymy się spać, jutro przed świtem musimy wyruszyć. Nie wiemy, gdzie są nasze brygady, nie możemy odgadnąć też, dlaczego obrały taki, a nie inny kierunek. Gdybym miał mapę, mógłbym z grubsza ustalić ich marszrutę. Tymczasem musi nam wystarczyć węch ${ }^{16}$.

Odniesienie do podstawowych mechanizmów biologicznych umożliwiających orientację, niemal zwierzęcych (węch), pokazuje bezradność człowieka wobec pokonywanej drogi. Osiągnięcia cywilizacyjne umożliwiające lepszą orientację w terenie (mapy) nie mogą się sprawdzić. Należy zawierzyć intuicji (egzystencjalistyczne odrzucenie racjonalizmu). Bliskość prawdziwego życia to również posiłki - kory drzew, rzadka w Dalmacji i spieczona przez słońce trawa.

Oddalający się cel podaje w wątpliwość oczekiwania czytelnika, a nawet horyzont czytelniczy tamtej epoki (akt podróżowania projektował bowiem pomyślne zakończenie). Czytelnik w trakcie lektury wątpi, czy ma do czynienia z opowieścią dającą pozytywne rozwiązanie (być może jest to związane z surrealistyczną aurą dominującą nad budową przestrzeni ${ }^{17}$ ). Na tym poziomie utwór odbiega od utopii komunistycznej, w której bohaterowie mogli napotykać trudności, ale cel musiał się zbliżać, musiała czuwać jakaś wyższa konieczność, jakaś dziejowa prawidłowość niczym ,wertykalizm” w Biblii, urzeczywistniony za pośrednictwem Opatrzności Bożej (Erich Auerbach). Omawiając odmienności kompozycyjne stosowane w narracjach antycznych i w Biblii, Auerbach już dawno wskazał na obecność „,wertykalnej” siły scalającej bieg zdarzeń, bowiem „,tylko ona potrafi w taki sposób zaplanować historię, i tylko ona może dostarczyć klucz do rozumienia dziejów"18. W przypadku powieści partyzanckiej nie chodzi rzecz jasna o Opatrzność Bożą (choć echa parareligijnego doświadczania świata pojawiały się we wczesnych powieściach o wojnie, a są obecne i tutaj), lecz o ciążącą na losie ludzkim konieczność dziejową, której celem jest zwycięstwo w wojnie i rewolucja. Partyzanci zatem pokonują niedogodności, ale w powieści Kaleba rozwiązanie wcale nie jest oczywiste: nie wiadomo, czy nad ich losem czuwa jakakolwiek wyższa konieczność; siłą ciążącą na ich losie jest bowiem przypadkowość. Ona oczywiście nie uchyla pozytywnego zakończenia, ale wyraźnie je osłabia.

Choć wyczekiwanie pomyślnego zakończenia wpływa na myślenie bohaterów i determinuje ich działania, ma się wrażenie, że wszystko jest odległe, coraz odleglejsze. Czytelnikowi wydaje się, że partyzanci nie dotrą do celu i umrą w zapomnieniu - na białym kamieniu Dalmacji (parafrazując inny utwór Kaleba). Tak jest przez większą część utworu. Pokonywanie rozdroży to konfrontacja z niemożliwym, ale witalizm i siła wewnętrzna partyzantów powodują, że nie jest to syzyfowa praca, ponieważ cały czas istnieje na horyzoncie szansa na dojście do celu. A on zbiega się z momentem, w którym do partyzantów przyłączają się mieszkańcy z okolicznych wsi. Powstaje nowy oddział, a kolektyw daje siłę.

16 Ibid., s. 26.

17 Krešimir Nemec zauważa, że dzikość przestrzeni ma charakter wręcz surrealistyczny. K. Nemec, Povijest hrvatskog romana od 1945. do 2000. godine, Zagreb 2003, s. 45.

18 E. Auerbach, Mimesis. Rzeczywistość przedstawiona w literaturze Zachodu, thum. Z. Żabicki, Warszawa 1968, s. 151. 
Dopiero grupa powoduje, że droga do celu zaczyna się skracać, że na horyzoncie pojawia się finał i sens podróży. I wtedy jeden z partyzantów wypowiada istotną kwestię: „Szosę też przejdziemy. Przejdziemy wszystko na świecie. Wydaje mi się, żeśmy się po to urodzili, aby przechodzić przez szosy, góry i rzeki”" ${ }^{\prime 1}$.

Po pozostawieniu nowych towarzyszy w napotkanym oddziale ich przemieszczanie się zaczyna być coraz bardziej sensowne. Kulminacyjny moment następuje wówczas, gdy spotkane na drodze partyzantki kładą poranionych Gołego i Chłopca na nosze i gdzieś ich zabierają - nie wiadomo gdzie, może do brygady. W tym momencie atmosfera staje się podniosła i zwiastuje szczęśliwe zakończenie podróży: „Mogę przejść jeszcze przez dziesięć gór! - powiedział na końcu Goły. I tak ruszyły. Zaczęły śpiewać. Sztandary na czele, a zaraz za sztandarami, niesieni obok siebie, dwaj partyzanci siedzieli rozparci na noszach jak dwaj bankierzy w drodze do Bombaju"20. I choć nie wiadomo, czy partyzanci znaleźli w końcu swoją brygadę czy nie, nie jest to aż tak istotne. Liczy się przede wszystkim to, że wędrowanie ku celowi miało sens, że warto było pokonywać trudności napotykane na drodze. Rozdroża były tylko chwilową przeszkodą. Nosze mogą być symbolem śmierci (trumna) albo tryumfu (podnoszenie zwycięzców), ale nawet jeśli przyjąć pierwszy wariant, to w tym wypadku śmierć można uznać za tryumf, bo symbolizuje lepszą przyszłość.

W powieści Šoljana podróż nie jest warunkowana sytuacją graniczną - wojną zagrażającą biologicznej egzystencji człowieka - lecz poszukiwaniem sensu życia. Ludzie żyjący po wojnie, ale odczuwający jej tragiczne doświadczenie, zostają skonfrontowani z ogólnym poczuciem bezsensu. Wycieczka w głąb Istrii, w poszukiwaniu jakiegoś klasztoru (Gradiny) ze średniowiecznymi freskami, wydaje się czymś ciekawym, co może chwilowo wypełnić poczucie dojmującej pustki egzystencjalnej. Kilkuosobowa ekspedycja, składająca się z młodych historyków sztuki i dziennikarzy, wyrusza w podróż pod przywództwem niejakiego Roka, który dzięki swojej charyzmie umiejętnie skupia wokół siebie ludzi skłonnych pójść za nim w nieznane ${ }^{21}$. Z czasem jednak - zwłaszcza po tym, jak awarii ulega autobus i wycieczka jest kontynuowana pieszo - okazuje się, że kolejni członkowie ekspedycji rezygnują z niej. Albo zostają w jakimś miejscu, albo zawracają. Ostatecznie pozostaje Roko i główny narrator opowiadający tę historię. Wydaje się, że właśnie między tymi dwiema postaciami rozgrywa się spór o istotę podróżowania, o istotę sensu istnienia, co umożliwia autorowi wyartykułowanie sprzeczności absurdu losu ludzkiego.

19 V. Kaleb, op. cit., s. 173.

20 Ibid., s. 199. Pierwsze zdanie („Mogę przejść jeszcze przez dziesięć gór! - powiedział na końcu Goły") zostało w polskim przekładzie pominięte.

21 Roko był wielokrotnie obiektem zainteresowania krytyki z dwóch powodów. Po pierwsze, zastanawiano się, skąd taki ,kapitan bez kompasu” (termin Branimira Donata) ma swoją charyzmę. Po drugie, próbowano w nim widzieć literacki odpowiednik Josipa Broza-Tito. A był przywódcą marnym nie tylko dlatego, że nie odnaleziono właściwego celu podróży, lecz także dlatego, że jego decyzja o skręceniu w lewo doprowadziła ekspedycję do przepaści. Sądzono zatem, wbrew oświadczeniom samego autora, że zaszyfrował on w powieści krytykę komunistycznego przywódcy. 
Gdy okazało się, że już dalej nie ma żadnej drogi, a klasztor jest rozsypującą się ruiną bez śladów średniowiecznych fresków, Roko beznamiętnie uznaje, że należy wracać, co u narratora wywołuje wybuch gniewu.

Prowadziłeś ludzi. Obiecywałeś. Oni mieli do ciebie zaufanie. Myśleli, tak jak i ja myślałem, że wiesz, gdzie nas prowadzisz... i dlaczego nas prowadzisz... wierzyli ci. Czemu nam wtedy nic nie powiedziałeś?22

\section{A Roko odpowiada:}

Nigdy nie ma nic na końcu. Ważne jest podróżowanie; porządek, dyscyplina. Zawsze ktoś musi prowadzić, a zdarzyło się, że to przypadkiem prowadziłem ja. Nie pozostaje człowiekowi nic innego niż starać się; zrobić coś, co jest najlepsze. I po to, żeby na końcu, Bóg wie który to już raz z rzędu, zrozumieć, że nie ma nic ${ }^{23}$.

I dodaje: „Każdy idzie swoją drogą. Ja szedłem swoją. Nasze drogi w niewielki sposób się ze sobą zbiegły”, a następnie: „Każdy idzie na swoją odpowiedzialność"24. Roko daje wykładnię filozofii egzystencjalizmu, z którą nie może się pogodzić narrator. Tak silnie tkwi w idealizmie, że przy pierwszym kontakcie z klasztorem wydaje mu się, iż widzi freski - przedstawienie danse macabre na ścianach. Jego pragnienie sensu jest tak duże, że tworzy projekcję celu (czytelnik przez moment nawet w nią wierzy), ale wkrótce okazuje się, iż jest to halucynacja, jakiś świat zastępczy, rekompensujący rozczarowanie.

W tym momencie dochodzi do ostatecznego rozpadu grupy. Roko wraca, a narrator wierzy w istnienie dalszej drogi, prowadzącej do nowego celu. I nagle udaje się do jakiegoś podziemnego tunelu, w którym znajduje się sam. Samotność i jej metafora - mrok umożliwiają mu konfrontację z życiem. Oglądamy człowieka takiego, jakiego widział Camus w Syzyfie, który po kolejnym nieudanym wydźwignięciu kamienia na szczyt schodzi ponownie w dół: „Twarz, która cierpi, sama jest już kamieniem. Widzę, jak ten człowiek schodzi ciężkim, ale równym krokiem ku udręce, której końca nie zazna. [...] Jeśli ten mit jest tragiczny, to dlatego, że bohater jest świadomy" ${ }^{25}$. Protagonista Šoljana z trudem przeciska się ku przodowi, ograniczany przez korzenie i wąskie przesmyki, a światła w tunelu nie widać. Wówczas następuje moment zasadniczy. Idzie po ziemi, na której leżą kości - kości tych, którzy, jak mówi, ,tu byli przed tobą”. W następującym monologu wyartykułowany zostaje najważniejszy problem książki:

Już nie jestem sam. Widzę nawet światełko w tunelu - czy to oczy, ostrza, pochodnie, detale na tarczach? Całe to milczące wojsko maszeruje obok mnie bez słowa. [...] Odczuwam z nimi milczącą wspólnotę. I nagle, nie widząc ich, rozpoznaję ich w mroku: to są moi przodkowie, tuż obok mnie. [...] Wchodzili jeden za drugim, na przestrzeni czasu, do tej zbawiennej ciemności, a teraz również, niektórzy już kilkaset lat, wciąż idą w tym niekończącym się pochodzie, niczym rzeka, której jestem częścią. [...] I wiem teraz, że moja droga, moje poszukiwanie nie było bezsensowne, ponieważ nie jestem sam, lecz przynależę

\footnotetext{
22 A. Šoljan, op. cit., s. 102-103.

Ibid., s. 103.

Ibid., s. 104.

5 A. Camus, op. cit., s. 108.
} 
do tej przepływającej rzeki, i kontynuuję ich drogę, nie tylko własną małą prywatną dróżkę prowadzącą przez bezsensowny czas, przez mroczne trzewia świata, ale również ich dążenie do celu, którego dotąd nie było mi dane widzieć, ale który musi istnieće ${ }^{26}$.

Ta halucynacja jest momentem przełomowym „w drodze życiowej” narratora. Uświadamia on sobie, że należy do rodzaju ludzkiego, który jest skazany na konieczność podróżowania przez życie (przez czas) bez szansy na odnalezienie założonego celu (sensu). Sensem zatem jest istnienie takie, jakie jest - to sztafeta bezsensownej egzystencji przekazywana z dziada na ojca, z ojca na syna. To prawdziwe danse macabre. Moment uświadomienia sobie nieodwołalności tragizmu losu ludzkiego zbiega się z końcem tunelu. Jest to jednocześnie „błyskotliwe zwycięstwo nad ciemnością, nad przeszłością, nad światem, nad sobą"27. Można to uznać za moment pogodzenia, zupełnie jak u Camusa: ,gdy zgłębi swoją udrękę, zamilkną bogowie. Cisza zostaje nagle przywrócona światu i słychać tysiące głosów ziemi"28. Żeby jednak tego ostatecznie dokonać, żeby się pogodzić, należy oddzielić się od grupy, skonfrontować się z samotnością i wrócić na łono kolektywu już odnowionym, niemal nowo narodzonym. Samotność jest warunkiem wstępnym zrozumienia istoty świata, a w ślad za tym zracjonalizowania potrzeby podróżowania.

Spuściłem głowę i wkraczając do krajobrazu, zaakceptowałem kamienistą drogę pod nogami, zaakceptowałem cierniste krzewy, które mnie ocierały po gołych rękach, zaakceptowałem głód i pragnienie i ból na odciśniętych stopach, które mnie będą męczyły dopóki nie dojdę do jakiegoś schronienia z ludźmi, zaakceptowałem cały ten dobrze znany, banalny i jałowy krajobraz, który miałem przed oczyma odkąd wyruszyliśmy w ten pochód ${ }^{29}$.

Świat to tragiczne zbiegi okoliczności, to dramat egzystencji, ale świadomość wspólnoty daje pocieszenie, zwłaszcza że nawiązuje do boskiego planu zbawienia - do męki Chrystusa (kamienista droga i cierniste krzewy).

Samotność jest zatem najważniejsza, zupełnie inaczej niż w powieści Urok pyłu, gdzie, przypomnijmy, Goły i Chłopiec przebywają cały czas razem. Co więcej, choć obaj protagoniści się różnią, są właściwie inwariantami jednej postaci - bohaterskiego partyzanta, noszonego wiarą w sprawiedliwość dziejową (być może dlatego właśnie nie mają imion). U Šoljana rzecz ma się zgoła inaczej każdy członek ekspedycji jest inny. Podróż rozpoczyna większa grupa ludzi, a kończy ją ledwie dwóch, a w jakimś sensie jeden. Podczas gdy w powieści Kaleba dochodzenie do celu opiera się na przezwyciężaniu osamotnienia poprzez powiększanie się grupy, w powieści Šoljana mamy do czynienia z czymś zupełnie odwrotnym - z rozpadaniem się grupy (Vladimir Biti uznał, że jest to węzłowy problem tej powieści, w jakimś sensie oddający nastrój generacji krugovašów ${ }^{30}$ ).

26 Ibid., s. 110.

27 Ibid., s. 111.

28 Ibid., s. 110.

29 Ibid., s. 112.

30 V. Biti, Upletanje nerečenoga: alegorija u krugovaškoj prozi šezdesetih godina [w:] Prostor u jeziku / Književnost i kultura šezdesetih, red. K. Mićanović, Zagreb 2009, s. 101-108. Generacja krugovašów, pisarzy urodzonych w latach dwudziestych i trzydziestych XX wieku, bierze swoją nazwę od środowiska literackiego skupionego wokół zagrzebskiego czasopisma „Krugovi”, które 
Warto też zwrócić uwagę na odmienność narratorów obu powieści. W pierwszej narrator jest, zgodnie z teorią Gérarda Genette'a, ekstradiegetyczny-heterodiegetyczny (nie uczestniczy w świecie przedstawionym, jest wobec niego zewnętrzny ${ }^{31}$ ), podczas gdy w drugim utworze ma on charakter intradiegetyczny-homodiegetyczny (opowiada swą własną historię). Ma to konsekwencje dla świata przedstawionego obu powieści. Podczas gdy pierwszy narrator usytuowany jest ,ponad” losami bohaterów (nie znaczy to, że nie ma on swoich preferencji w ich opisie), drugi jest częścią opowieści, jej zaangażowanym ogniwem. W pierwszym przypadku mamy do czynienia z próbą obiektywizacji świata przedstawionego, w drugim - z radykalną subiektywizacją, opowieścią własnej wizji świata. W powieści Kaleba zatem partyzanci zmierzają do jakiegoś celu, który za sprawą konieczności dziejowej - muszą niechybnie osiągnąć. Obserwujemy to z zewnętrz, jako coś niepodlegającego dyskusji. W Krótkiej wyciecze podróżowanie, jako alegoria przechodzenia przez życie, jest dramatem osobistym, który nie może szukać oparcia w żadnych siłach dziejowych ani duchowych. Bohater jest zdany sam na siebie, podobnie jak czytelnik.

Omawiając wątek podróży w powieści Kaleba, Pavličić proponuje dwie możliwe interpretacje. W myśl tej pierwszej, którą uznaje za bardziej wiarygodną, cel podróży postawiony przed człowiekiem jest złudny, ponieważ nigdy nie można go osiągnąć. Tak więc opowieść o dwóch partyzantach jawi mu się jako „opowieść o nieuniknionej porażce oraz o godności, z jaką się tę porażkę przyjmuje"32. Dowodem jest jego zdaniem koniec utworu - nosze symbolizują bowiem śmierć. Jak już była mowa, śmierć można jednak potraktować jako tryumf, zwłaszcza że tej scenie towarzyszy atmosfera podniosła. Jest to więc nowe życie - w tym czy innym świecie. Wydaje się zatem, że partyzanci wcale nie przegrywają, lecz przeciwnie - odnoszą zwycięstwo. Wprawdzie nie odnajdują brygady, ale jednak pokonują przeszkody i przybywają na wolne terytorium; ratują życie, wielokrotnie zagrożone, i z nadzieją patrzą w przyszłość. A przyszłość jawi się jako zbiór kolejnych celów. Taka interpretacja jeszcze wyraźniej dochodzi do głosu, gdy porównamy powieść Kaleba z Krótka wycieczką. U Šoljana bohater nie dochodzi do celu, lecz uświadamia sobie dramat egzystencji polegający na tym, że nie istnieje żaden cel. Nie jest zwrócony ku przyszłości („mogę przejść jeszcze dziesięć gór"), lecz zanurzony w przeszłości (przodkowie), nie wzbija się ku gó-

zapoczątkowało proces odchodzenia od socrealizmu na rzecz pluralizmu wypowiedzi artystycznej. Generacja ta, jak odnotował Biti w innym artykule, nie chciała „wykorzystywać przeszłości do brukowania drogi ku przyszłości” (V. Biti, Doba svjedočenja. Tvorba identiteta u suvremenoj hrvatskoj prozi, Zagreb 2005, s. 176). Zrehabilitowano literaturę określaną dotąd mianem „reakcyjnej”, i to zarówno rodzimą, jak i zachodnią. Akcentowano wolność i indywidualizm twórczy, a jednocześnie rolę tradycji (niewątpliwe echa wizji T.S. Elliota, tłumaczonego zresztą na łamach czasopisma). Na ten temat zob. np. D. Detoni-Dujmić, Krugovi, Zagreb 1995.

31 Pavao Pavličić zauważył, że narrator w powieści Kaleba, mimo iż sprawia wrażenie „obiektywnego" i wszechwiedzącego, jest stylistycznie nacechowany. Przejawia się to w „dawkowaniu” informacji na temat świata przedstawionego. Przekazuje rzeczy, które wydają się nieistotne, o rzeczach ważnych zaś milczy.

32 P. Pavličić, op. cit., s. 23. 
rze (nosze), lecz znajduje się na dole (tunel) ${ }^{33}$. Pogodzenie się z tym faktem jest pogodzeniem się z dolą Syzyfa, który pokonuje trudy bez nadziei ich ostatecznego przezwyciężenia, ale właśnie w tej swojej beznadziejności odnajduje jakiś sens. Takie potraktowanie tej sceny bliższe jest drugiej interpretacji zasugerowanej przez Pavličicia, którą badacz uznaje za mniej prawdopodobną. W niej dolę partyzantów przedstawia się inaczej - doszli do celu, choć ten cel inaczej sobie wyobrażali. To iluzja dawała im siłę, napędzała ich działanie, ale gdy się okazało, że to tylko projekcja, wcale się nie rozczarowali, lecz zaakceptowali decyzję losu. „Jest zupełnie jak w życiu, ponieważ nie wiemy, jaki jest nasz prawdziwy cel, lecz nam się dopiero z czasem objawia" ${ }^{34}$.

Choć w obu utworach pojawiają się elementy typowe dla powieści egzystencjalistycznej (człowiek rzucony w świat, niemogący w pełni nad nim zapanować; przypadkowość decydująca o biegu zdarzeń; egzystencja, a nie esencja jako $d a$ tum w życiu), jest w nich też witalizm, umożliwiający przezwyciężenie egzystencjalistycznego nihilizmu, z którym rozliczał się Camus w Człowieku zbuntowanym. Kluczem jest pogodzenie się. Być może taki „pogodny” egzystencjalizm dałoby się powiązać z Camusowską „myślą słoneczną”, wyłożoną najpełniej w Zaślubinach ${ }^{35}$. Camus pisał: ,jestem dumny ze swojej doli człowieczej. [...] Ależ tak, jest powód: słońce, morze, moje serce pulsujące młodością, moje ciało o smaku soli i ta olbrzymia sceneria, w której czułość i uniesienie łączą się w żółcieni i błękicie" ${ }^{36}$.

Wydaje się jednak, że Camus jest bliższy Šoljanowi niż Kalebowi. U Kaleba bowiem nadziei nie daje Natura, jak u Camusa, lecz Historia (jak u Sartre'a). Nie chcę przez to powiedzieć, że obaj są pod wpływem francuskich pisarzy, lecz że zachodzi tutaj pewne powinowactwo (oczywiście i wpływu nie można wykluczyć, choć chorwaccy badacze przyjmują, że na Šoljana większy wpływ miała literatura angloamerykańska, a nawet Zamek Kafki). Nie jest to też dowód na to, że Kaleb jest bliższy marksizmowi, leninizmowi czy maoizmowi, jak Sartre, a Šoljan jest krytykiem tych doktryn (choć nie znaczy, że teza ta jest nieprawdziwa, ale trzeba by na jej potwierdzenie przeprowadzić zupełnie nową argumentację); idzie raczej o to, że Kaleb - mimo wszystko - widzi dla człowieka nadzieję w tworzeniu lepszego świata, w zbiorowym trwaniu ludzkości. Šoljan przeciwnie - skłania się ku przekonaniu o absurdalności ludzkiego

33 Vladimir Biti analizował rolę świata na dole w literaturze generacji krugovašów, ale ponieważ interesowały go inne zagadnienia, a swoją argumentację budował na teorii psychoanalitycznej, doprowadziło go to do zupełnie innych rozstrzygnięć (zob. V. Biti, Doba svjedočenja ..., s. 173-190).

34 P. Pavličić, op. cit., s. 23.

35 Można tę myśl sprowadzić do formuły „śródziemnomorskiego egzystencjalizmu”, zob. A. Lunić, Između književnosti i filozofije: egzistencijalizam mediteranskog kruga. Albert Camus i Antun Šoljan, „Filozofska istraživanja” 2015, 137, god. 35, sv. 1, s. 67-87. Analizując filozofię Camusa, Waleria Szydłowska stwierdza, że Śródziemnomorze jest źródłem tego doświadczenia: „Na tej drodze nie potrzeba wartości, nie trzeba budować kolejnych poziomów metafizyki i nadziei; ona sama powinna wszystko wyjaśnić. Powinna, jak słońce Tipasy, oświetlić prawdę: że nie ma nic prócz kamieni i że to wystarczy, by się nie zabić". Zob. W. Szydłowska, Egzystencjalizm w kontekstach polskich. Szkic o doświadczeniu, myśleniu i pisaniu powojennym, Warszawa 1997, s. 32.

36 A. Camus, Zaślubiny. Lato, tłum. M. Leśniewska, Kraków 1981, s. 11. 
istnienia, którego się nie da rozwiązać, ale z którym trzeba umieć żyć, czy wręcz nauczyć się z nim żyć. Ważne jest to, co człowiek przeżywa, indywidualne doświadczenie absurdu (można tu wyczuć echa egzystencjalizmu chrześcijańskiego Kirkegaarda i Szestowa, ale Šoljanowi bliżej do Camusa, który wprawdzie przyjmował antyracjonalizm, ale nie odwoływał się do doświadczenia wiary i Boga, no chyba że pośrednio ${ }^{37}$ ). Stąd właśnie punktem zwrotnym w Krótkiej wycieczce, i w innych powieściach Šoljana, jest samotność. Bohaterowie Kaleba nie są samotni - wszystko przeżywają wspólnie, nie są wygnańcami; przeciwnie - ich droga urzeczywistnia się w gromadzie. W pierwszym wypadku istnieje cel, a więc rozwiązanie absurdu, pokonanie go (absurdalna jest tylko droga), w drugim jest absurd istnienia i prowadzi donikąd (nie ma takiej drogi). Stąd już bliżej pierwszemu autorowi do heglizmu; i stąd już bliżej mu do Sartre'a, który wprawdzie określał się mianem egzystencjalisty, ale - inaczej niż Kirkegaard, Szestow czy Camus - wierzył w rozum, tworzył system i naukową teorię mogącą opisać absurd istnienia. Kaleb jest wciąż w pewnym sensie utopistą, podporządkowuje człowieka wielkiej historii, koniecznościom dziejowym, Šoljan jest pogodzonym sceptykiem, nieufnym wobec Historii, dla niego liczy się człowiek w konfrontacji ze sobą, w spotkaniu z przyrodą.

Być może zatem najlepszą definicją bohaterów obu powieści byłyby mityczne figury buntowników: Prometeusza i Syzyfa, bo jak zauważyła Waleria Szydłowska - Syzyf ,zmaga się z absurdem sam-na-sam, Prometeusz szuka sprzymierzeńców. Idzie do ludzi, żeby razem z nimi naprawiać świat [...] Domeną walki Syzyfa jest egzystencja, absurd ontologiczny, domeną walki Prometeusza - historia, czyli absurd wartości" 38 .

\section{Bibliografia}

Auerbach E., Mimesis. Rzeczywistość przedstawiona w literaturze Zachodu, thum. Z. Żabicki, Warszawa 1968.

Biti V., Upletanje nerečenoga: alegorija u krugovaškoj prozi šezdesetih godina [w:] Prostor u jeziku / Književnost i kultura šezdesetih, ed. K. Mićanović, Zagreb 2009, s. 101-108.

Biti V., Doba svjedočenja. Tvorba identiteta u suvremenoj hrvatskoj prozi, Zagreb 2005.

Camus A., Mit Syzyfa, thum. J. Guze, Warszawa 2001.

Camus A., Zaślubiny. Lato, tłum. M. Leśniewska, Kraków 1981.

Flaker A., Zašto „,Divota prašine”? [w:] Komparativna povijest hrvatske književnosti: zbornik radova VIII. (Hrvatske književnost prema europskim lemisija i recepcijal 1940-1970) sa znanstvenoga skupa održanog 22-23. rujna 2005. godine u Splitu, red. C. Pavlović, V. Glunčić-Bužančić, Split 2006, s. 279-286.

Kaleb V., Przydrożny pyt, thum. Z. Stoberski, Warszawa 1957.

37 Camus w Micie Syzyfa pisał otwarcie: ,[...] dla Szestowa rozum jest nieskuteczny, ale poza rozumem coś istnieje. Dla umysłu absurdalnego rozum jest nieskuteczny i nic nie ma poza nim"

(A. Camus, Mit Syzyfa, s. 35).

38 W. Szydłowska, op. cit., s. 38. 
Lakoff G., Johnson M., Metafory w naszym życiu, thum. T.P. Krzeszowski, Warszawa 1988.

Lunić A., Između književnosti i filozofije: egzistencijalizam mediteranskog kruga. Albert Camus i Antun Šoljan, „Filozofska istraživanja” 2015, 137, god. 35, sv. 1, s. $67-87$.

Milanja C., Hrvatski roman 1945-1990. Nacrt moguće tipologije hrvatske romaneskne prakse, Zagreb 1996.

Nemec K., Povijest hrvatskog romana od 1945. do 2000. godine, Zagreb 2003.

Pavličić P., Divota prašine kao alegorija, „Adrias” 2011, nr 17, s. 9-30.

Šoljan A., Kratki izlet, Zagreb 2004.

Szydłowska W., Egzystencjalizm w kontekstach polskich. Szkic o doświadczeniu, myśleniu i pisaniu powojennym, Warszawa 1997.

Wieczorkiewicz A., Wędrowcy fikcyjnych światów. Pielgrzym, rycerz i włóczęga, Gdańsk 1996. 